\title{
The impact of analytical CRM on strategic CRM, operational CRM and customer satisfaction: Empirical study on commercial banks
}

\author{
Bader Almohaimmeed $^{\mathrm{a}^{*}}$
}

${ }^{a}$ Department of Business Administration, College of Business and Economics (CBE), Qassim University, Al Malida, Buraydah 52571, Saudi Arabia

\section{H R O N I C L E}

Article history:

Received November 20, 2020

Received in revised format

January, 28, 2021

Accepted April 102021

Available online

April 122021

Keywords:

Analytical CRM

Strategic CRM

Operational CRM

Customer satisfaction

Commercial banks

\begin{abstract}
A B S T R A C T
The aim of this study is to identify the effect of the analytical customer relationship management (CRM) on strategic CRM, operational CRM and customer satisfaction. Data collected from a sample consisted of 150 managers of managers in commercial banks using a questionnaire. The results accepted the hypotheses that analytical CRM is positively related to both strategic CRM and operational CRM, which in turn show significant effects on customer satisfaction. Analytical CRM had no significant direct effect on customer satisfaction, but through strategic CRM and operational CRM. Such results indicated that strategic CRM and operational CRM had a full mediation role between the analytical CRM and customer satisfaction. It was concluded based on these results that CRM components, i.e., analytical, strategic and operational CRM are all critical in ensuring customer satisfaction. Therefore, banks should consider all these components in designing their CRM programs.
\end{abstract}

\section{Introduction}

Customer satisfaction, which is the ultimate aim that organizations seek to ensure, is very critical for organizations' continuity and success. Several benefits are expected because of customer satisfaction like profitability. Therefore, factors affecting customer satisfaction had gained great attention. One vein of the literature guided by different theoretical foundations emphasized the importance of customer relationship for customer satisfaction. In such a vein, numerous studied were took place on the relationship between customer relationship management (CRM) and customer satisfaction (Battor \& Battor, 2010; Khong \& Yao, 2011; Adalikwu, 2012; Graf et al., 2013; Azzam, 2014; Hassan et al., 2015; Adikaram \& Khatibi, 2016; Santouridis \& Veraki, 2017; Aldaihani \& Ali, 2018; Johan et al., 2020). Generally, the results of such studies revealed that CRM had a significant effect on customer satisfaction (e.g., Hassan et al., 2015; Rahimi \& Kozak, 2017; Bhakane, 2015; Krishnamoorthy \& Anaandavel, 2014). Some studies found that the effect of CRM on customer satisfaction was mediated by other variables such as customer knowledge (Mithas, Krishnan \& Fornell, 2005) and customer empowerment (Aldaihani \& Ali, 2018). In a review of CRM literature, Bin-Nashwan \& Hassan (2017) found that CRM had been conceptualized using three dimensions, which are service quality, service access, and handling customer complaints. Other dimensions were used for CRM such as employee behavior, relationship development, and interaction management (Long et al., 2013), competence, trust, commitment, relationship quality, and customer experience (Krishnamoorthy \& Anaandavel, 2014), in addition to relationship initiation, relationship maintenance, and relationship termination (Reinartz, Krafft \& Hoyer, 2004). For some authors (e.g., Dyche, 2002), CRM is divided into two types: analytical CRM and operational CRM. Analytical CRM, which was termed "the back office of CRM", is responsible for understanding customers through customer data analysis, while operational CRM, which was called "the front office of CRM", is responsible for supporting organization-customer interactions by underpinning customer service (Gunawan et al., 2013). * Corresponding author

E-mail address: bmam@qu.edu.sa (B. Almohaimmeed)

(C) 2021 by the authors; licensee Growing Science. doi: $10.5267 /$ j.uscm.2021.4.007 
Buttle \& Maklan (2019) added a third component, i.e., strategic CRM, which refers to the strategy used by the organization to identify its profitable customers and to make them loyal customers by developing customer business strategy (Tanner Jr. et al., 2005). Khodakarami \& Chan (2014) examined three types of CRM, analytical CRM, operational CRM, and collaborative CRM. For them, collaborative CRM is responsible for integration of interaction touch points and communications through systems such as e-mails and websites.

Due to the importance of CRM components (i.e., strategic, analytical, and operational), many studies were conducted to highlight the effects of such components (e.g., Ranjan, 2009; Liu, 2015; Ayyagari, 2019; Khodakarami \& Chan, 2014; Wahlberg et al., 2009). Hence, organizations are called for an adequate integration of CRM components in order to achieve the benefits of CRM like customer satisfaction, customer loyalty and competitive advantage (Garcia, Pacheco \& Martinez, 2012; Gunawan et al., 2013). CRM is a concept of designing offers for customers based on their behaviors (Garcia, Pacheco \& Martinez, 2012), which means that customer data analysis through analytical CRM is a pivotal part of CRM. It can be performed by applications such as data mining and data warehousing (Khodakarami \& Chan, 2014). The most important point in this regard is that operation CRM feeds analytical CRM by customer data. The latter analyses customer data and provides both strategic CRM and operation CRM parts with the results of data analysis. Such results are useful for attracting profitable customers, i.e., strategic CRM (Buttle \& Maklan, 2019), and to enhance customer services (Iriana \& Buttle, 2007). It was expected that analytical-CRM results in an effective implementation of CRM, particularly through improving processes of both strategic CRM and operational CRM, which in turn have significant effects on customer satisfaction. Therefore, this study seeks to investigate the effect of analytical CRM on strategic CRM and operational CRM, and to examine the effect of the three components of CRM on customer satisfaction. In addition to that, analytical CRM processes are directed to internal objects, while processes of strategic CRM and operational CRM are oriented to internal and external objects like employees and customers. In order to highlight the importance of strategic CRM and operational CRM, the mediating effects of these two variables on the effect of analytical CRM on customer satisfaction was tested.

The reminder of the study is structured as follows. Section 2 provides a review of the literature and logics behind hypotheses development. Section 3 emphasizes research methodology through presenting the sample of the study, its model, instrument, as well as initial analysis related to factor reduction, reliability, validity, and measurement model fit. Section 4 illustrates the empirical results of the study along with discussions. Section 5 demonstrates the conclusion of the study and its implications. Next, study contribution was reported in section 6 , followed by study limitations and future research directions in section 7.

\section{Literature review and hypotheses development}

\subsection{Customer relationship management (CRM)}

The domain of strategic customer management consists of three components: customer management, relationship marketing, and CRM. Customer management refers to the tactical management of customer interactions, while relationship marketing is concerned with strategic management of stakeholder relationships. On the other hand, CRM describes strategic management of customer relationships including technology use (Payne \& Frow, 2013). Buttle \& Maklan (2019) identified three types of CRM: strategic CRM, analytical CRM, and operational CRM. The strategic part of CRM conceptualizes the strategy followed to identify customers who are profitable in order to make them loyal customers. The automation of sales, marketing and customer services are embodied in the operational part of CRM. Analytical CRM is a process of transforming customer data into usable form for the purpose of strategic or operational CRM.

According to Tanner Jr. et al. (2005), strategic CRM is related to decisions made to develop customer business strategy, business process and culture, as well as to support technology models, while analytical CRM refers to customer and market information analysis to be used in the achievement of the company's strategic marketing. Finally, operational CRM symbolizes business processes performed to meet the objectives of customer relationship models. Iriana \& Buttle (2007) indicated that the aim of strategic CRM is to attract and retain profitable customers, the aim of analytical CRM is to look up business decisions through customer data analysis, and the aim of operational CRM is to enhance the efficiency of daily customer operations. Khodakarami and Chan (2014) added that analytical CRM is utilized to predict customer behavior using systems like data warehousing, data mining, and online analytical processing (OLAP). On the other hand, operational $\mathrm{CRM}$ is used to increase the efficiency of the CRM process through automation of sales force, marketing automation, and customer service systems.

Analytical CRM, strategic CRM and operational CRM were used in the current study as three dimensions of CRM and this can be justified through considering the aim of this study and the intended contribution that the study would add to CRM literature. The majority of the previous studies on CRM regarded it as a whole construct and therefore selected several dimensions to assess such a construct. Examples of CRM dimensions in the literature include customer orientation, CRM organization, knowledge management, technology-based CRM (Mohammed \& Rashid, 2012; Abdullateef, Mokhtar \& Yusoff, 2010; Mohammad, bin Rashid \& bin Tahir, 2013; Chetioui, Abbar \& Benabbou, 2017), top management support, customer data, customer orientation, customer information-processing and integration, training orientation (Rafiki, Hidayat \& Razzaq, 2019). Other studies used service quality, CRM system integration, employee behavior, solving customer problems, and customer database (Iriqat \& Daqar, 2018), customer identification, customer attraction, customer 
development, and customer retention (Ngai, Xiu \& Chau, 2009), and customer experience, value proposition, employee behavior, and relationship development (Saleh \& Saheli, 2018).

\subsection{Customer satisfaction}

Customer satisfaction was regarded as a major objective for any organization, particularly banks (Velnampy \& Sivesan, 2012). Customers are satisfied if some conditions are met. First, customers judge products or services based on their expectations (Simanjuntak et al., 2020). If the actual performance of the product or the service is in line with their expectations, they are satisfied. For example, some customers evaluate the quality of a service they experienced through comparing their perceptions of products or services' performance with their expectations of such a performance. Second, some customers have no expectation but evaluate products and services through comparing those products and services with their values, i.e., their needs, and desires in preference to their expectations (Parker \& Mathews, 2001). Third, customers who are involved in transaction relationships evaluate products and services by comparing their net gains with a reference group (Bodet, 2008; Parker \& Mathews, 2001). Generally, some scholars defined customer satisfaction as the overall customer evaluation of products and services (Gustafsson, Johnson \& Roos, 2005). In CRM context, customer satisfaction could be measured by identifying the extent to which customer needs are fulfilled through CRM activities (AlRefaie, Li \& Ko, 2012).

\subsection{Effects of ACRM on SCRM and OCRM}

Customer data is very useful for organizations seeking to develop long and strong relationships with their customers. Many benefits of customer data analysis were reported such as predicting customer switch, retaining customers, predicting revenues and their related risks in addition to identifying customer responses to marketing offers (Yan, Wolniewicz \& Dodier, 2004). In fact, these benefits emphasize the importance of customer behavior analysis. According to Chen, Chiu \& Chang (2005), organizations are able to develop good relationships with customers through predicting changes in their behaviors. This means that customer data analysis constitutes a critical component of customer relationship management. Kracklauer, Mills \& Seifert (2004) indicated that customer behavior analysis is the foundation of CRM. Customer data collection and analysis can be performed using analytical CRM. Analytical CRM is a process of customer behavior discovery using different technology-based applications like sales analysis, customer profile analysis, campaign analysis, customer contact analysis, loyalty analysis as well as profitability analysis (Kelly, 2000). Results of such applications are delivered across the organization for strategic or operational objectives (Iriana \& Buttle, 2007). According to Kim (2008), using customer information by designing good customer databases helps organizations determine their profitable customers. That is, analytical CRM assists organizations to perform their strategic directions. Therefore, it was expected that:

\section{$\mathrm{H}_{1}$ : There is a significant effect of analytical CRM on strategic CRM.}

\section{$\mathrm{H}_{2}$ : There is a significant effect of analytical CRM on operational CRM.}

\subsection{Effects of strategic and operational CRM on customer satisfaction}

In order to investigate the mediating role of strategic CRM and operational CRM in the effect of analytical CRM on customer satisfaction, the effect of both strategic and operational CRM on customer satisfaction should be examined. Generally, the application of CRM increased customer satisfaction (Er, 2020). For Mithas, Krishnan \& Fornell (2005) indicated that the effect of CRM applications on customer satisfaction could be explained through three reasons related to CRM features such as enabling organizations to customize customers' offerings, enhancing customer experience through providing them with prompt services and accurate order processing, and improving the effective management of customer relationships. Strategic CRM as a part of CRM is directed to attracting profitable customers Buttle \& Maklan (2019) and therefore considers their needs and desires, which is assumed to enhance their satisfaction. Operational CRM is used to improve the efficiency of customers' daily operations and therefore assumed to enhance their satisfaction (Iriana \& Buttle, 2007). Consequently, the following hypotheses were speculated:

\section{$\mathrm{H}_{3}$ : There is a significant effect of strategic CRM on customer satisfaction.}

\section{$\mathrm{H}_{4}:$ There is a significant effect of operational CRM on customer satisfaction.}

\subsection{Effects of ACRM on customer satisfaction}

According to Doyle (2002), analytical CRM can be used by organizations to analyze customer behavior and to develop personalized communication with customers. The most important role of analytical CRM is to combine customer knowledge from different resources in contrast to operational CRM, which is best for customer socialization (Khodakarami \& Chan, 2014). Analytical CRM was expected to show no direct effect on customer satisfaction. This was due to the nature of analytical CRM, as a back office part of CRM (Dyche, 2002), that concentrates on mining of customer data to guide the strategic intentions and the operational activities directed to management of customer relationships. Being that, both strategic CRM and operational were anticipated to mediate the effect of analytical CRM on customer satisfaction. Strategic CRM was conceptualized using customer orientation and customer value (Kim \& Lee, 2020). It consists of processes of strategy development (business strategy and customer strategy) and value creation for the organization and its customers 
(Iriana \& Buttle, 2007). Operational CRM was conceptualized using customer service automation (Khodakarami \& Chan, 2014) as well management of physical and virtual communication channels (Iriana \& Buttle, 2007). Therefore, the following hypotheses was suggested:

\section{$\mathrm{H}_{5}$ : There is a significant effect of analytical CRM on customer satisfaction.}

$\mathrm{H}_{6}$ : Strategic CRM mediates the effect of analytical CRM on customer satisfaction.

$\mathrm{H}_{7}$ : Operational CRM mediates the effect of analytical CRM on customer satisfaction.

\section{Methodology}

\subsection{Research sample and data collection}

Managers from all management levels in commercial banks comprise the population of the study. A sample consisting of 150 managers was selected to collect the required data using a five-point Likert questionnaire developed based on previous studies. One hundred and fifty questionnaires were distributed and 131 were returned complete and valid for the purpose of data analysis with a response rate of $87.3 \%$. The sample consisted of line managers $(52 \%)$, middle managers $(36 \%)$, and top managers $(18 \%)$.

\subsection{Research model}

The study seeks to test six hypotheses as shown in Fig. 1. Analytical CRM (ACRM) was assumed to exert significant effects on strategic CRM, operational CRM as stated in $\mathrm{H}_{1}, \mathrm{H}_{2} \& \mathrm{H}_{2}$. Strategic CRM and operational CRM were presumed to show significant effects on customer satisfaction (CSAT) as in $\mathrm{H}_{3} \& \mathrm{H}_{4}$. ACRM was assumed to show non-significant effect on customer satisfaction, and both strategic CRM as well as operational CRM were assumed to mediate the effect of analytical CRM on customer satisfaction as in $\mathrm{H}_{5}, \mathrm{H}_{6}$ \& $\mathrm{H}_{7}$.

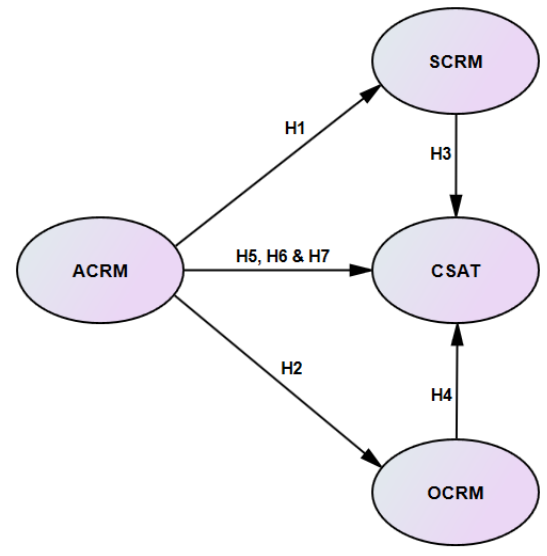

Fig. 1. Conceptual model

\subsection{Measures}

Measures of research variables are shown in Table 1 . The questionnaire consisted of 16 items distributed on analytical CRM (4 items), strategic CRM (4 items), operational CRM (4 items) and customer satisfaction (4 items). These items were selected based on the results of exploratory factor analysis (EFA) as clarified in the next sub-section.

Table 1

Research measures

\begin{tabular}{|c|c|c|}
\hline Variables & Items & References \\
\hline $\begin{array}{l}\text { Analytical } \\
\text { CRM }\end{array}$ & $\begin{array}{l}\text { 1. } \text { Our CRM project aims at building a customer database } \\
\text { 2. Customer data are analyzed to support sales and marking activities } \\
\text { 3. Results of customer data analysis are delivered to managers } \\
\text { 4. Customer information is collected and shared across the bank }\end{array}$ & Iriana \& Buttle (2007) \\
\hline Strategic CRM & $\begin{array}{l}\text { 5. Our resources are allocated to improve customer value } \\
\text { 6. Our objective is to ensure customer engagement } \\
\text { 7. Customer satisfaction and retention are core objectives for us } \\
\text { 8. Customer profiles are constructed based on customer data analysis }\end{array}$ & $\begin{array}{l}\text { Buttle \& Maklan (2019); } \\
\text { Iriana \& Buttle (2007) }\end{array}$ \\
\hline $\begin{array}{l}\text { Operational } \\
\text { CRM }\end{array}$ & $\begin{array}{l}\text { 9. Our CRM project aims at reducing costs of customer operations } \\
\text { 10. Customer service processes are automated to increase their efficiency } \\
\text { 11. Sales processes are automated to be more efficient and effective }\end{array}$ & Iriana \& Buttle (2007) \\
\hline $\begin{array}{l}\text { Customer } \\
\text { satisfaction }\end{array}$ & $\begin{array}{l}\text { 12. We understand our customer's needs } \\
\text { 13. We pay our customers individual attention } \\
\text { 14. Our staff are willing to help customers } \\
\text { 15. We help customers solve their bank-related problems } \\
\text { 16. Surveys of our customers indicate that they are satisfied }\end{array}$ & $\begin{array}{l}\text { Verma \& Chaudhuri } \\
\text { (2009) }\end{array}$ \\
\hline
\end{tabular}




\subsection{Exploratory factor analysis (EFA)}

EFA was used to categorize research variables. Some conditions should be met to perform EFA. First, a ratio of variables to respondents should be no less than 10:1 (Yong \& Pearce, 2013). For the current study, the ratio was 33:1. Second, data should be explored for sampling adequacy and factorability. Kaiser-Meyer-Olkin Measure of Sampling Adequacy (KMO) and Bartlett's Test of Sphericity can be used in this regard. According to García-Santillán, Venegas-Martinez \& Escalera (2013), KMO value is preferable when it is higher than 0.5 and Bartlett's Test of Sphericity should be significant. Factor loadings are assumed to be greater than 0.60 (Ehido et al., 2020). Such conditions were met as shown in Table 2.

Table 2

Results of EFA

\begin{tabular}{|c|c|c|c|c|c|}
\hline Variable & Items & Factor loadings & AVE & $\mathbf{C R}$ & $\alpha$ \\
\hline \multirow[t]{4}{*}{ Analytical CRM } & ACRM1 & 0.732 & \multirow{4}{*}{0.530} & \multirow{4}{*}{0.819} & \multirow{4}{*}{0.838} \\
\hline & ACRM1 & 0.739 & & & \\
\hline & ACRM1 & 0.717 & & & \\
\hline & ACRM1 & 0.724 & & & \\
\hline \multirow[t]{4}{*}{ Strategic CRM } & SCRM1 & 0.737 & \multirow{4}{*}{0.521} & \multirow{4}{*}{0.813} & \multirow{4}{*}{0.777} \\
\hline & SCRM2 & 0.726 & & & \\
\hline & SCRM3 & 0.721 & & & \\
\hline & SCRM4 & 0.702 & & & \\
\hline \multirow[t]{4}{*}{ Operational CRM } & OCRM1 & 0.786 & \multirow{4}{*}{0.533} & \multirow{4}{*}{0.820} & \multirow{4}{*}{0.856} \\
\hline & OCRM2 & 0.699 & & & \\
\hline & OCRM3 & 0.734 & & & \\
\hline & OCRM4 & 0.698 & & & \\
\hline \multirow[t]{4}{*}{ Customer satisfaction } & CSAT1 & 0.792 & \multirow{4}{*}{0.712} & \multirow{4}{*}{0.908} & \multirow{4}{*}{0.915} \\
\hline & CSAT2 & 0.856 & & & \\
\hline & CSAT3 & 0.854 & & & \\
\hline & CSAT4 & 0.870 & & & \\
\hline
\end{tabular}

Based on the results of factor loadings and the average factor extracted (AVE), values of composite reliability (CA) higher than 0.70 (Lin, 2007) and Cronbach's alpha coefficients higher than 0.70 (Ehido et al., 2020) confirm reliability. Convergent validity was tested using AVE values. Such values should be no less than 0.50 (Campos, Carrascosa \& Maroco, 2012). Consequently, the results in Table 2 indicate that both reliability and validity were assured all CR and alpha values were greater than 0.7 and AVE values were greater than 0.50 .

\subsection{Confirmatory factor analysis (CFA)}

CFA was used to check the measurement model fit. Following Lin (2007), four indices were used: The goodness-of-fit index (GFI), the comparative fit index (CFI), the normed fit index (NFI), and the root mean square error of approximation (RMSEA). Based on the recommended values of these indices as shown in Table 4, it was noted that the measurement model exhibited a good fit with the current data.

Table 4

Measurement model fit

\begin{tabular}{cccc}
\hline Index & Current value & Recommended value & Result \\
CMIN/DF & 2.87 & $<3.0$ & Accepted \\
GFI & 0.831 & $>0.80$ & Accepted \\
CFI & 0.921 & $>0.90$ & Accepted \\
RMSEA & 0.063 & $<0.08$ & Accepted \\
\hline
\end{tabular}

\section{Empirical results and discussion}

Hypotheses were tested via the structural model shown in Figure 2. The requirements of the model goodness-of-fit were met, i.e., $\mathrm{CMIN} / \mathrm{DF}=1.577$ (less than 3), GFI $=0.876$ (higher than 0.80), CFI $=0.950$ (higher than 0.90), and RMSEA = 0.067 (less than 0.08) (Lin, 2007). Fig. 2 shows the hypothesized relationships between CRM components (ACRM, SCRM, and OCRM) and customer satisfaction. H1 assumed that ACRM exerts a significant effect on SCRM. The results as shown in Table 5 display that the standardized total effect of ACRM on SCRM is significant $(\beta=0.275, P=0.016)$, which means that H1 was supported. Similarly, the standardized total effect of ACRM on OCRM is significant $(\beta=0.454, \mathrm{P}=0.001)$. As for the effects of SCRM and OCRM on customer satisfaction, the results indicated that both SCRM and OCRM were significantly and positively related to customer satisfaction $(\beta=0.292, \mathrm{P}=0.017, \beta=0.308, \mathrm{P}=0.008)$ respectively. These results supported H3 \& H4. On the other hand, H5 hypothesized that ACRM exerts a significant effect on customer satisfaction. It was noted that the standardized total effect of ACRM on customer satisfaction is significant $(\beta=0.338, \mathrm{P}=$ $0.001)$. However, the results illustrated that there is no significant direct significant effect of ACRM on customer satisfaction $(\beta=0.117, P=0.227)$ but a significant indirect effect of $A C R M$ on customer satisfaction $(\beta=0.22, P=0.001)$.

In order to investigate the mediating role of both SCRM and OCRM in the effect of ACRM on customer satisfaction, H6 and $\mathrm{H} 7$ were suggested. The results clarified that there was a significant effect of SCRM on customer satisfaction $(\beta=$ $0.292, P=0.017)$ and a significant effect of OCRM on customer satisfaction $(\beta=0.308, P=0.008)$. Whereas there was a significant direct effect of ACRM on customer satisfaction, there was a significant indirect effect of ACRM on customer 
satisfaction through both SCRM and OCRM. Consequently, H6 \& H7 were accepted. This result suggests that SCRM and OCRM have a full mediating role in the relationship between ACRM and customer satisfaction.

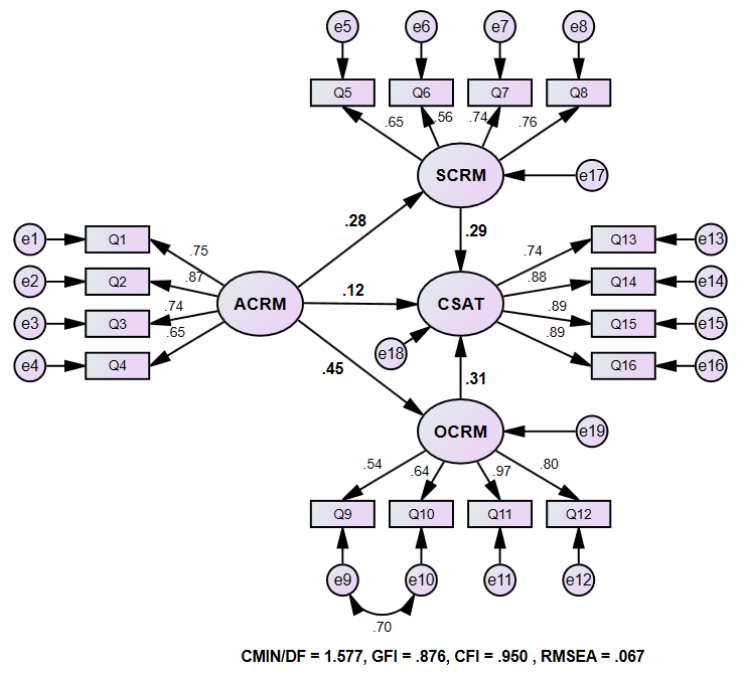

Fig. 2. Structural model

Table 5

Results of hypotheses testing

\begin{tabular}{|c|c|c|c|c|c|c|c|c|}
\hline \multirow{2}{*}{ IV } & \multirow{2}{*}{$\rightarrow$} & \multirow{2}{*}{ DV } & \multicolumn{2}{|c|}{ Stand. total effects } & \multicolumn{2}{|c|}{ Stand. direct effect } & \multicolumn{2}{|c|}{ Stand. indirect effects } \\
\hline & & & $\beta$ & $\mathrm{P}$ & $\beta$ & $\mathrm{P}$ & $\beta$ & $\mathrm{P}$ \\
\hline ACRM & $\rightarrow$ & SCRM & 0.275 & 0.016 & 0.275 & 0.016 & - & - \\
\hline ACRM & $\rightarrow$ & OCRM & 0.454 & 0.001 & 0.454 & 0.001 & - & - \\
\hline SCRM & $\rightarrow$ & CSAT & 0.292 & 0.017 & 0.292 & 0.017 & - & - \\
\hline OCRM & $\rightarrow$ & CSAT & 0.308 & 0.008 & 0.308 & 0.008 & - & - \\
\hline ACRM & $\rightarrow$ & CSAT & 0.338 & 0.001 & 0.117 & 0.227 & 0.22 & 0.001 \\
\hline $\mathrm{P}$ is signific & .05 & & & & & & & \\
\hline
\end{tabular}

In line with the current results, researchers (e.g., Kracklauer, Mills \& Seifert, 2004; Yan, Wolniewicz \& Dodier, 2004; Chen, Chiu \& Chang, 2005) emphasized the importance of customer data analysis as a main component of CRM. Therefore, ACRM assists the organization to perform its operations and to achieve its strategic directions in an effective manner. In terms of the effects of SCRM and OCRM on customer satisfaction, previous studies indicated that SCRM is concerned with attracting profitable customers and therefore to meet their needs and make them satisfied customers. As well, OCRM was assumed to increase customer satisfaction due to its role in enhancing the effectiveness of customer-related operations (Mithas, Krishnan \& Fornell, 2005; Er, 2020; Iriana \& Buttle, 2007; Buttle \& Maklan, 2019). It was concluded based on other previous studies (e.g., Doyle, 2002; Khodakarami \& Chan, 2014; Kim \& Lee, 2020; Iriana \& Buttle, 2007) that ACRM had no significant effect on customer satisfaction. Such a conclusion was not supported by the current results, while the mediating role of SCRM and OCRM in the effect of ACRM on customer contribution was accepted.

\section{Conclusion and implications}

CRM is vital for marketing success. The aim of this study was to examine the effect of ACRM on customer satisfaction through both SCRM and OCRM. The study found that ACRM was positively related to customer satisfaction, SCRM and OCRM. Moreover, it was found that SCRM and OCRM mediated the effect of ACRM on customer satisfaction. However, there is no direct effect of ACRM on customer satisfaction, which means that the effect of ACRM on customer satisfaction is attributed to its indirect effect through SCRM and OCRM. These results confirmed that the components of CRM, i.e., ACRM, SCRM and OCRM are positively related to each other. Based on these results, organizations are required to consider the three components of CRM similarly. ACRM is very important for implementing CRM systems due to its effects on SCRM and OCRM, which also constitute pivotal components in terms of their effects on customer satisfaction and their mediating role. In the absence of these two components, ACRM shows no significant effect on customer satisfaction.

\section{Study contribution}

Numerous studies were conducted on CRM. However, no studies were found on the effect of analytical CRM, strategic CRM and operational CRM on customer satisfaction. Hence, the study contributed to CRM literature through conceptualizing CRM as a construct encompassing these three dimensions, i.e., ACRM, SCRM, and OCRM. All these dimensions had significant effects on customer satisfaction. Nevertheless, the effect of ACRM could be realized through SCRM and OCRM. Researchers are called for measuring CRM using items that cover these entire dimensions, and organizations should align their CRM initiative with their business strategy and integrate such an initiative with their organizational culture and customer daily operations in order to ensure a successful implementation of CRM. 


\section{Limitations and Future research directions}

This study is limited to a small sample size selected from commercial banks to study the effect of CRM in terms of three dimensions, i.e., analytical, strategic, and operational CRM. Therefore, the results of the study cannot be generalized to other sectors. Researchers should use more sample sizes to confirm the current results collecting data from different industries.

\section{References}

Abdullateef, A. O., Mokhtar, S. S., \& Yusoff, R. Z. (2010). The impact of CRM dimensions on call center performance. International Journal of Computer Science and Network Security, 10(12), 184-195.

Adalikwu, C. (2012). Customer relationship management and customer satisfaction. African Journal of Business Management, 6(22), 6682-6686.

Adikaram, C. N. K., \& Khatibi, A. (2016). The relationship between customer relationship management and customer satisfaction: A study on private higher education institutions in Sri Lanka. International Journal of Arts and Commerce, 5(2), 69-95.

Akhil, P., Hareesh, k. U. R., \& Akhil, W S. (2020). A study on customer relationship management practices in hospitality industry with special reference to travel operators and five star hotels in Kerala. UGC Care Journal, 19(4), 493-498.

Aldaihani, F. M. F., \& Ali, N. A. B. (2018). Impact of social customer relationship management on customer satisfaction through customer empowerment: A study of Islamic Banks in Kuwait. International Research Journal of Finance and Economics, 170, 41-53.

Al-Refaie, A., Li, M. H., \& Ko, J. H. (2012). Factors affecting customer linking capabilities and customer satisfaction in CRM: Evidence from Jordanian hotels. International Journal of Customer Relationship Marketing and Management (IJCRMM), 3(4), 16-30.

Ayyagari, M. R. (2019). A framework for analytical CRM assessments challenges and recommendations. International Journal of Business and Social Science, 10(5), 5-13.

Azzam, Z. A. M. (2014). The impact of customer relationship management on customer satisfaction in the banking industry-a case of Jordan. European Journal of Business and Management, 6(32), 99-112.

Battor, M., \& Battor, M. (2010). The impact of customer relationship management capability on innovation and performance advantages: testing a mediated model. Journal of Marketing Management, 26(9-10), 842-857.

Bhakane, B. (2015). Effect of customer relationship management on customer satisfaction and loyalty. International Journal of Management (IJM), 6(5), 01-07.

Bodet, G. (2008). Customer satisfaction and loyalty in service: Two concepts, four constructs, several relationships. Journal of Retailing and Consumer Services, 15(3), 156-162.

Buttle, F., \& Maklan, S. (2019). Customer relationship management: Concepts and technologies. NY: Routledge.

Campos, J. A. D. B., Carrascosa, A. C., \& Maroco, J. (2012). Validity and reliability of the Portuguese version of Mandibular function impairment questionnaire. Journal of Oral Rehabilitation, 39(5), 377-383.

Chen, M. C., Chiu, A. L., \& Chang, H. H. (2005). Mining changes in customer behavior in retail marketing. Expert Systems with Applications, 28(4), 773-781.

Chetioui, Y., Abbar, H., \& Benabbou, Z. (2017). The impact of CRM dimensions on customer retention in the hospitality industry: Evidence from the Moroccan Hotel sector. Journal of Research in Marketing, 8(1), 652-660.

Doyle, S. (2002). Software review: Communication optimisation - the new mantra of database marketing. Fad or fact? Journal of Database Marketing, 9(2), 185-191.

Dyche, J. (2002). The CRM Handbook. New York: Addison-Wesley.

Ehido, A., Awang, Z., Halim, B. A., \& Ibeabuchi, C. (2020). Developing items for measuring quality of work life among Malaysian academics: An exploratory factor analysis procedure. Humanities \& Social Sciences Reviews, 8(3), 1295-1309.

$\mathrm{Er}$, W. K. (2020). A Study on relationship between customer relationship management (CRM) and customer satisfaction on Taobao Website in Johor Bahru. Journal of Arts \& Social Sciences, 3(2), 1-14.

Garcia, I., Pacheco, C., \& Martinez, A. (2012). Identifying critical success factors for adopting CRM: A framework for small and medium enterprises. Software Engineering Research, Management and Applications, 430, 1-15.

García-Santillán, A., Venegas-Martinez, F., \& Escalera, M. E. (2013). Attitude toward Statistic in College Students (An Empirical Study in Public University). Journal of Statistical and Econometric Methods, 2(1), 43-60.

Graf, M., Schlegelmilch, B. B., Mudambi, S. M., \& Tallman, S. (2013). Outsourcing of customer relationship management: Implications for customer satisfaction. Journal of Strategic Marketing, 21(1), 68-81.

Gunawan, A., Kornarius, Y. P., Aulia, A. A., Gunawan, T. and Elisabet, I., Chandra, I., \& Anggana, P. (2013). Competing by restaurant analytical CRM. Proceedings of the International Conference: Small and Medium Sized Enterprises in a Global World. Romania, 25-28 September 2013, 112-124.

Gustafsson, A., Johnson, M. D., \& Roos, I. (2005). The effects of customer satisfaction, relationship commitment dimensions, and triggers on customer retention. Journal of Marketing, 69(4), 210-218.

Hassan, R. S., Nawaz, A., Lashari, M. N. and Zafar, F. (2015). Effect of customer relationship management on customer satisfaction. Procedia Economics and Finance, 23(12), 563-567.

Iriana, R., \& Buttle, F. (2007). Strategic, operational, and analytical customer relationship management: attributes and measures. Journal of Relationship Marketing, 5(4), 23-42.

Iriqat, R. A., \& Daqar, M. A. M. A. (2018). The mediating role of customers' satisfaction on the effect of CRM on long-term customers loyalty in the banking sector in the Palestinian territory. Asian Social Science, 14(8), 76-90.

Johan, M. R. M., Annuar, N., Joseph, J. S., \& Kumar, S. K. (2020). Satisfaction Determinants of Airlines Industry in Malaysia. Jurnal Intelek, 15(2), 87-100.

Kelly, S. (2000). Analytical CRM: the fusion of data and intelligence. Interactive Marketing, 1(3), 262-267. 
Khodakarami, F., \& Chan, Y. E. (2014). Exploring the role of customer relationship management (CRM) systems in customer knowledge creation. Information \& Management, 51(1), 27-42.

Khong, K. W., \& Yao, H. I. (2011). Effectiveness of customer relationship management on customer satisfaction in the commercial banks of Taiwan. Contemporary Management Research, 7(2), 106-116.

Kim, B. Y. (2008). Mediated effects of customer orientation on customer relationship management performance. International Journal of Hospitality \& Tourism Administration, 9(2), 192-218.

Kim, H., \& Lee, Y. (2020). A structural model of customer relationship management (CRM) strategies, rapport, and learner intentions in lifelong education. Asia Pacific Education Review, 21(1), 39-48.

Kracklauer, A.H., \& Mills D.Q., Seifert D. (2004) Customer Management as the Origin of Collaborative Customer Relationship Management. In: Kracklauer A.H., Mills D.Q., Seifert D. (eds) Collaborative Customer Relationship Management. Springer, Berlin, Heidelberg. https://doi.org/10.1007/978-3-540-24710-4_1

Krishnamoorthy, V., \& Anaandavel, V. C. (2014). Does customer relationship management improve customer satisfaction and customer loyalty in retail banking. Saiom Journal of Commerce Management, 1(8), 1-15.

Lin, H. F. (2007). Effects of extrinsic and intrinsic motivation on employee knowledge sharing intentions. Journal of Information Science, 33(2), 135-149.

Liu, C. H. (2015). A Conceptual Framework of Analytical CRM in Big Data Age. International Journal of Advanced Computer Science and Applications, 6(6), 194-152.

Long, C. S., Khalafinezhad, R., Ismail, W. K. W., \& Abd Rasid, S. Z. (2013). Impact of CRM factors on customer satisfaction and loyalty. Asian Social Science, 9(10), 247-253.

Mithas, S., Krishnan, M. S., \& Fornell, C. (2005). Why do customer relationship management applications affect customer satisfaction?. Journal of Marketing, 69(4), 201-209.

Mohammad, A., bin Rashid, B., \& bin Tahir, S. (2013). Assessing the influence of customer relationship management (CRM) dimensions on organization performance. Journal of Hospitality and Tourism Technology, 4(3), 228-247.

Mohammed, A. A., \& Rashid, B. (2012). Customer Relationship Management (CRM) in Hotel Industry: A framework proposal on the relationship among CRM dimensions, Marketing Capabilities, and Hotel performance. International Review of Management and Marketing, 2(4), 220.

Ngai, E. W., Xiu, L., \& Chau, D. C. (2009). Application of data mining techniques in customer relationship management: A literature review and classification. Expert Systems with Applications, 36(2), 2592-2602.

Parker, C., \& Mathews, B. P. (2001). Customer satisfaction: contrasting academic and consumers' interpretations. Marketing Intelligence \& Planning, 19(1), 38-44.

Payne, A., \& Frow, P. (2013). Strategic customer management: Integrating relationship marketing and CRM. Cambridge: Cambridge University Press.

Rafiki, A., Hidayat, S. E., \& Razzaq, D. A. A. (2019). CRM and organizational performance. International Journal of Organizational Analysis.

Rahimi, R., \& dKozak, M. (2017). Impact of customer relationship management on customer satisfaction: The case of a budget hotel chain. Journal of Travel \& Tourism Marketing, 34(1), 40-51.

Ranjan, J. (2009). Role of Analytical CRM in CRM Systems: Importance and Benefits. Management \& Change, 13(1), 169-188.

Reinartz, W., Krafft, M., \& Hoyer, W. D. (2004). The customer relationship management process: Its measurement and impact on performance. Journal of Marketing Research, 41(3), 293-305.

Saleh, L., \& Saheli, E. (2018). The impact of CRM strategy on customer loyalty in SMEs. International Business Research, 11(11), 37-45.

Santouridis, I., \& Veraki, A. (2017). Customer relationship management and customer satisfaction: the mediating role of relationship quality. Total Quality Management \& Business Excellence, 28(9-10), 1122-1133.

Simanjuntak, M., Putri, N. E., Yuliati, L. N., \& Sabri, M. F. (2020). Enhancing customer retention using customer relationship management approach in car loan bussiness. Cogent Business \& Management, 7(1), 1-17.

Tanner Jr, J. F., Ahearne, M., Leigh, T. W., Mason, C. H., \& Moncrief, W. C. (2005). CRM in sales-intensive organizations: A review and future directions. Journal of Personal Selling \& Sales Management, 25(2), 169-180.

Velnampy, T., \& Sivesan, S. (2012). Customer relationship marketing and customer satisfaction: A study on mobile service providing companies in Srilanka. Global Journal of Management and Business Research, 12(18), 318-324.

Verma, S., \& Chaudhuri, R. (2009). Effect of CRM on Customer Satisfaction in Service Sector in India. Journal of Marketing \& Communication, 5(2), 55-69.

Wahlberg, O., Strandberg, C., Sundberg, H., \& Sandberg, K. W. (2009). Trends, topics and under-researched areas in CRM research: a literature review. International Journal of Public Information Systems, 3, 191-208.

Yan, L., Wolniewicz, R. H., \& Dodier, R. (2004). Predicting customer behavior in telecommunications. IEEE Intelligent Systems, 19(2), 50-58.

Yong, A. G., \& Pearce, S. (2013). A beginner's guide to factor analysis: Focusing on exploratory factor analysis. Tutorials in Quantitative Methods for Psychology, 9(2), 79-94.

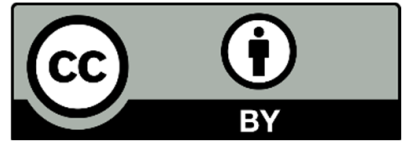

(C) 2021 by the authors; licensee Growing Science, Canada. This is an open access article distributed under the terms and conditions of the Creative Commons Attribution (CC-BY) license (http://creativecommons.org/licenses/by/4.0/). 